\title{
MODERNISATION OF THE ARMOURED COMPONENT OF THE RUSSIAN FEDERATION'S GROUND FORCES IN THE YEARS 2015-2018. AN OUTLINE OF THE SUBJECT
}

\begin{abstract}
Ten years after the collapse of the Soviet Union and a relatively short period of hegemony of the United States, a period of change led to a clear formation of a new polycentric geopolitical order. The theses about the "end of history" presented by Francis Fukuyama in 1989 did not evolve, although they confirmed closure of the Cold War era. In the first years of the 21 st century, especially after the economic crises (2008), the policies of the major states on the international scene increased assertiveness in external relations. This was particularly true of Russia, which - since Vladimir Putin took power on December 31, 1999 - focused on the rebuilding of the empire, and marked the boundaries of the failed superpower. The Kremlin's actions resulted in the war with Georgia in 2008, the seizure of the Crimea in 2014, and the intervention in Syria in 2015. In spite of demographic problems, the expansion of Western economic sanctions and relatively low oil and gas prices, which are the main source of income for the country, the 2008 modernisation of the Russian armed forces, was continued. The aim of the paper is to report the latest trends in the scale and scope of modernisation of the armoured component of Russian Ground Forces in the years 2015-2018 and the factors that had a direct impact on current conditions resulting from the emergence of the "new Cold War" in Russia's relations with the West after 2014.
\end{abstract}

Keywords: Russia, imperialism, ground forces, tanks, modernisation, state security.

\section{INTRODUCTION}

The Russian Federation's invasion of Georgia in 2008 highlighted the relatively low efficiency of Russian Ground Forces and became a key impetus for a major boost to previous reform plans in this regard (Galeotti, 2017; Grabowski, 2011; Haas, 2011; Depczyński, 2017). They resulted in significant qualitative changes (both in the introduction of new types of weaponry, modernization of existing ones, and changes in the way they were used on the battlefield), which could already be observed during the occupation of Crimea and activities

\footnotetext{
${ }^{1}$ Leszek Pawlikowicz, DSc, PhD, Associate Professor, Department of Historical and Theoretic Legal Science of the University of Rzeszów, ul. Grunwaldzka 13, 35-068 Rzeszów; e-mail: pawlikowicz69@interia.pl (corresponding author). ORCID: 0000-0002-4389-1937.

2 Krzysztof Surowiec PhD, Department of Humanities and Social Sciences, Faculty of Management, Ignacy Łukasiewicz Rzeszów University of Technology, ul. Podkarpacka 1, 35-082 Rzeszów; e-mail: ks@prz.edu.pl. ORCID: 0000-0002-6298-2260.
} 
in the Donbass carried out since February 2014 (Galeotti, 2019; Kofman, Migacheva, Nichiporuk, Radin, Tkacheva, Oberholtzer, 2017; Bowen, 2019), or on a smaller scale - during the Russian intervention in Syria launched in September 2015 (Barrie, Gethin, 2018). The improvement in the above-mentioned type of armed forces was caused in particular (except for the decline in the two years following the crisis of 2008), the favorable economic situation in 2000-2014, when oil and gas prices increased, which translated into a systematic increase in outlays, both in the broadly understood Russian power departments and the arms sector.

Despite undoubted successes, some changes in the process of modernization of Russian land forces can be observed since 2015. The aim of the article is to answer the following questions: what was the general direction of development of Russian Ground Forces in 2015-2018, including in particular the scope of the modernization of their armoured component, and what factors directly affected their dynamics and scale.

In the field of methodology of inference, the following methods were used: empirical, quantitative and comparative.

\section{DEMOGRAPHIC POTENTIAL AND ECONOMY POWER AND ITS IMPACT ON MILITARY EXPENDITURE}

The population of the Russian Federation in 2015 had 144,096,870 inhabitants, while in 2018 - 144,478,050 inhabitants, so it increased by only 381,180 people. Comparing the current (according to 2018 data) demographic potential of Russia, e.g. to the analogous potential of the United States (327,166,434 million inhabitants), European Union countries (513,133,363 inhabitants), or even relatively small Bangladesh (161.356.039 inhabitants), it can be concluded that, unlike the former Soviet Union (which had 293.047.571 inhabitants in July 1991), the modern Russian Federation is no longer able to play an equal role in this respect against the countries it considers to be potential adversaries ${ }^{3}$.

In turn, the Russian economy in the years 2015-2016 fell into recession (although the growth dynamics amounted then to: $-2.31 \%$ and $+0.33 \%$, respectively, comparing year-toyear at current prices of the ruble, due to the significant level of inflation the same indices calculated according to the current US dollar prices were much more pessimistic: $-33.81 \%$ for 2015 and $-5.93 \%$ for 2016$)^{4}$. The return to growth took place only from $2017(+1.63 \%$ year-on-year according to current ruble prices in 2017 and $+2.25 \%$ in 2018, and according to current dollar prices by $+23.07 \%$ and $5.00 \%$, respectively) ${ }^{5}$.

\footnotetext{
${ }^{3}$ In the scope of demographic data from 2014-2018, it was based on World Bank data, while in the scope of analogous data referring to the USSR on the data of the Central Intelligence Agency. See: (World Bank Data: Total Population - World's Countries, https://data.worldbank.org/indicator/SP.POP.TOTL? locations=RU; The World Factbook 1991, Central Intelligence Agency, Washington D.C. 1991).

${ }^{4}$ In 2016, Russia's GDP fell to USD 1,282.7 billion (at current prices) and was the lowest level since 2009, when it amounted to USD 1,222.6 billion (at current prices). See: (World Bank Data: GDP (current US\$) - Russian Federation, https://data.worldbank.org/indicator/NY.GDP.MKTP. CD? end $=2018 \&$ locations $=$ RU\&start $=1999 \&$ view $=$ chart ).

${ }^{5}$ In 2017, Russia's GDP increased to USD 1,578.6 billion (at current prices), and a year later to USD 1,657.6 billion (at current prices). See: (World Bank Data: GDP (current US\$) - Russian Federation, https://data. worldbank.org/indicator/NY.GDP.MKTP.CD? end=2018\& locations=RU\&start=1999 \&view=chart).
} 
Although the GDP per capita of the Russian Federation increased between 2015 and 2018 from USD 9,313.8 to USD 11,288.9 (in current prices), and the Russian economy in terms of GDP (calculated in current prices of USD) rose from 12 in 11 th place in the world, it still remained 3.3\% smaller than the Canadian economy, $25.1 \%$ smaller than the Italian one, 2.41 times the German one and as much as 12.36 times the American one ${ }^{6}$.

Economic problems of 2015-2016 were reflected in military expenditure. The latter amounted (according to SIPRI data) at that time, respectively: 4,047 trillion rubles $(4.9 \%$ of GDP) and 4,645 trillion rubles (5.5\% of GDP), however their amount calculated in current USD prices (according to IISS data) dropped from 66.1 billion to 57.2 billion. In turn, in the years 2017-2018 there was their nominal and percentage decrease (according to SIPRI) to: 3,880 trillion rubles (4.2\% of GDP) and 3,850 trillion rubles (3.9\% of GDP) respectively. Paradoxically, however, their value calculated in current USD prices (according to IISS data) began to increase: from 61.7 billion in 2017 to 63.1 billion in $2018^{7}$.

\section{DYNAMICS OF CHANGES IN THE GROUND FORCES OF THE RUSSIAN FEDERATION IN THE YEARS 2015-2018}

From December 1, 2010, the Ground Forces of the Russian Federation (Russian: Сухопутные войска Российской Федераџии), after the fifth, since the creation of the new state, the territorial reform of the armed forces, was subordinated to the command of four military districts: the West (the Central Command with the command) in Yekaterinburg), South (with command in Rostov-on-Don) and East (with command in Khabarovsk) (The Military Balance 2011...; Galeotti, 2017; Russia Military Power. Building a Military to Support Great Power Aspirations, 2017; Jane's World Armies 2018).

According to data from the prestigious International Institute for Strategic Studies in London, between January 2015 and January 2018 the number of Ground Forces of the RF increased from 230,000 officers and soldiers (through 240,000 in January 2016 and 270,000 in January 2017) to 280,000 in January 2017, and therefore by as much as $21.7 \%$ (The Military Balance 2015...; The Military Balance 2016...; The Military Balance 2017...; The Military Balance 2018...).

In the same period, the number of operational and operational-tactical associations increased: army commands from 10 to 12 (increase by 20\%) and corps commands from 0 to 1 (absolute increase).

In turn, in the case of tactical relationships, the total number of divisions increased from 4 to 8 (an increase by $100 \%$ ), including: tank divisions from 1 to 2 (an increase by $100 \%$ ) and motor-rifle divisions from 2 to 5 (an increase by 150\%). Only the number artillery divisions remained unchanged (1). Their creation (based on previously functioning brigades)

\footnotetext{
${ }^{6}$ See for more information on GDP per capita in 2015 and 2018 and global GDP rankings in 2015 and 2018 (respectively): World Bank Data: GDP per capita (current US\$) - World's Countries, https://data.worldbank.org/indicator/ NY.GDP.PCAP.CD; World Bank Data: GDP (current US\$) World's Countries, https://data.worldbank.org/indicator/NY.GDP.MKTP.CD?end=2015\&most_ recent_value_desc=true; World Bank Data: GDP (current US\$) - World's Countries https://data.worldbank.org/indicator/NY.GDP.MKTP.CD?end=2018\&most_recent_value_desc= true.

7 SIPRI Military Expediture Database. Data for all countries 1949-2018 (excel spreadsheet): (https://www.sipri.org/databases/milex; The Military Balance 2017...; The Military Balance 2018...; The Military Balance 2019...; See: (Martynenko, Parkhitko, 2018).
} 
led to a decrease in the number of existing (in the form of "independent" units) analogous types of brigades: tank brigades from 3 to 2 (a decrease of 33.3\%) and independent motorrifle brigades from 30 to 25 (a decrease by $16.7 \%$ ). Only changes in the number of independent light or mountain motor-rifle brigades were not recorded (3).

For most other types of brigades there was a noticeable, and in some cases very significant, increase in their number (respectively): artillery from 8 to 9 (an increase by 12.5\%), heavy artillery from 0 to 1 (an absolute increase), anti-aircraft missile defense from 9 to 14 (an increase of as much as 55.6\%), operational-tactical missile brigades from 9 to 11 (an increase of $22.2 \%$ ), special forces (Spetsnaz) from 7 to 8 (an increase of 14.3\%), diagnoses from 1 to 2 (up to $100 \%$ increase). However, the number of brigades did not change: rocket artillery (4), engineering (4), logistics (10), protection against weapons of mass destruction (5) and military police (1).

In turn, at the level of "independent" regiments, a significant increase in their number was recorded in the range of (respectively): special forces from 0 to 1 (an absolute increase) and protection against weapons of mass destruction from 0 to 10 (an absolute increase). On the other hand, the number of rocket artillery regiments decreased from 1 to 0 (an absolute decline $)^{8}$.

For armaments and equipment of the Ground Forces, the focus was not on quantitative growth, but on qualitative changes, as evidenced by the fact that from January 2015 to January 2018, the number of basic combat tanks in combat units increased from just 2,600 to 2,780 units (an increase of 6.9\%), infantry fighting vehicles from over 5,125 to 5,140 (up by just $0.3 \%$ ), armoured personnel carriers from over 6,000 to over 6,100 (up by $1.7 \%$ ), self-propelled guns from 1,500 to 1,596 (up by $6.4 \%$ ), multiple rocket launchers from over 850 to over 862 (an increase of less than $1.8 \%$ ). The number of self-propelled guns/mortars (over 80), towed guns/mortars (100), towed mortars (1,500), towed anti-tank guns (526) remained unchanged, while the number of self-propelled anti-aircraft rocket launchers even slightly decreased from over 1,570 to 1,520 (i.e. by $3.2 \%$ ). The only exceptions among the types of armaments whose number increased significantly were: operational tactical missiles launchers (where an increase from 120 to 144, i.e. by 20\%) and self-propelled mortars (increase from 0 to 40, i.e. an absolute increase) (The Military Balance 2015; The Military Balance 2018).

\section{MODERNIZATION OF THE ARMOURED TROOPS IN 2015-2018}

The largest qualitative changes taking place within the Ground Forces of the Russian Federation referred in particular to their armoured component. Expected at least since the Yom Kippur war in 1973, the twilight of the main battle tanks as an effective means of warfare - in spite of the passage of several decades - proved to be premature (Ogorkiewicz, 2015). In May 2015, the Russians publicly presented the first fifth generation tank in the world: the T-14 "Armata". Despite the not very successful "debut", it was planned to buy 2,300 units by 2020 , but the original intentions - due to technical problems difficult to solve in a short time and a high unit price (estimated at USD 3.7 million, which was a lower level

8 (The Military Balance 2015...; The Military Balance 2018...). The creation of four new divisions in 2015-2018 clearly contradicted the reverse process implemented in 2008-2009 under the socalled reform of Serdyukov (holding the office of the Minister of Defense of the Russian Federation between February 2007 and November 2012). See: (The Military Balance 2011...; Galeotti, 2017; Sutyagin, Bronk, 2017; Russia Military Power...; Wolski, 2019; Depczyński, 2018). 
anyway compared to the prices of analogous tanks of Western countries) - reduced in April 2016 to 100 copies, and then - in August 2018 - to only 32 copies (except for about 20 preseries created in 2015-2016), of which 9 should enter arming by the end of 2019 (Galeotti, 2017; Jane's Land Warfare Platforms..., 2018; Defence24: Czotgi Armata do produkcji seryjnej po 2018 roku...; Defence24: Zamówienia na rosyjskie...; Defence24: Sabak, https://www.defence24.pl/ czolg-t-14-armata-gotow-do-prob-panstwowych).

The T-14 equipped with an unmanned turret armed with a $125 \mathrm{~mm} 2 \mathrm{~A} 82-1 \mathrm{M}$ gun ${ }^{9}$ is to use sub-caliber anti-tank missiles: 3BM69 "Vacuum-1" (Russian: 3БM69 "Вакуум-1") with a uranium core and 3BM70 "Vacuum-2" (Russian: 3БM70 "Вакуум-2") with a tungsten core with armour penetration capability comparable only to a similar American M829A3 shell (also with a 120mm uranium core, developed for newer versions of the Abrams M1A1, M1A2 tank) ${ }^{10}$, and additionally have the ability to fire from the mentioned cannon anti-tank guided missiles 9K119M "Refleks-M" with a range of $5.000 \mathrm{~m}$ (Jane's Land Warfare..., 2018). In addition to the new type of "Malachite" reactive armour, the T14 - as the first tank in the world - is also to have an active defense system called "Afghanit", used to detect, track and capture (using radar) in a 360 degree radius in the horizontal sphere (not including the vertical sphere) of enemy anti-tank missiles moving at speeds up to $1.700 \mathrm{~m} / \mathrm{s}$ (5.0 Ma), and then disrupting the operation of hostile guidance systems (perhaps using a laser beam) and destroying the incoming missiles by launching their own anti-fire projectiles (or similar elements using kinetic energy) ${ }^{11}$. Also new is the placement of a crew of three in a specially armoured capsule providing protection against enemy sub-caliber armour-piercing shells at an equivalent level exceeding $900 \mathrm{~mm}$ of rolled homogeneous armour (RHA), which will increase the ability to survive on the battlefield without the need to significantly increase the weight of the tank (estimated at 48-49 tons, during when the mass of the latest version of the Abrams M1A2C tank reaches 66.8 tons), providing good maneuverability (speed $90 \mathrm{~km} / \mathrm{h}$ and range $500 \mathrm{~km}$ ) (Bender, These are the plans...; Nikonov, 2018).

Lack of financial possibilities ensuring the launch of "Armata" on a larger scale forced the implementation of a less expensive, but also less ambitious solution, i.e. modernization of already used types of tanks. In 1992-2015 - apart from the production of subsequent versions of a relatively new type of T-90 tank, adopted for arming in October 1992, although being a development of the late versions of the T-72B (Russian: $T-725)^{12}$, whose number

\footnotetext{
9 During the first tests carried out in 2002, the 2A82 gun was to demonstrate muzzle energy of approx. 15.3 MJ, i.e. approx. 17\% higher than the German Rheinmetall Rh-120/L55 high-pressure gun used in the latest versions of the German Leopard tanks 2A6, 2A6M and 2A7. See: (WeapoNews.com: Tank T-14...; Roblin, https://nationalinterest.org/blog/buzz/no-silver-bullet-why-russias-new-tank-round-has-problem-54862).

10 The penetration of the 3BM69 Vacuum-1 missile is estimated at a minimum $900 \mathrm{~mm}$ RHA at an angle of $60^{\circ}$ in relation to the flight path at a shot from a distance of 2,000 m, while the $3 \mathrm{BM}-70$ Vacuum-2 at $800 \mathrm{~mm}$ RHA at an analogous angle and at identical distance. In turn, M829A3 pierces 800 mm RHA. See: (Wolski, 2016).

11 Defence Update: (Eshel, New Russian Armor...).

${ }^{12}$ From October 1992 to September 1995, 107 T-90 and T-90K tanks were produced for the Ground Forces of the FR, between 1996 and 2003 - 64, in the years 2004-2012 an additional 337 copies of the new variant T-90A, and in addition - during 2018 - 62 tanks in a very advanced version of the T-90M. See: (Suworow, 2003; Wolski, 2018a; Wolski 2018b; Wolski, 2019; Przeździecki, 2017c; Jane's Land Warfare..., 2018; Kwasek, 2018).
} 
did not change between January 2015 and in January 2018 (350 copies in the T-90 and T-90A versions) (The Military Balance 2015...; 186; The Military Balance 2018...). - a few hundred T-80 and T- $72^{13}$ tanks were also modernized to a limited extent.

However, the relatively most advanced modernization program that took place in 20152018 was initiated in June 2010 and concerned the reconstruction of the T-72 to the T-72B3 standard (Russian: T-7253), which has a modified fire control system "Kalina" and 2A46M5 cannon $^{14}$. By January 2015, about 400 modernized tanks of this version were adopted for armament, and in the next three years (until January 2018) their number increased to 800 copies and an additional 80 in the T-72B3M (Russian: T-72Б3M) version, also referred to as T-72B3 Mod. 2016 (Russian: T-72Б3 обр. 2016) (The Military Balance 2015...; The Military Balance 2018...), with a new engine with $34.5 \%$ more power and a slightly improved 2A46M-5-01 gun (Przeździecki, 2017a; Wolski, 2019). Between January 2015 and January 2018, the number of remaining T-72 tanks that were not in the armament, but not covered by the modernization, dropped from 1,300 to 1,100 units (versions T-72B and T-72BA) (The Military Balance 2015...; The Military Balance 2018...), which means that about 680 of 880 modernized vehicles were not in combat units, but in reserve (Wolski, 2019).

In September 2017, a proposal to modernize the T-80 tanks was also presented, whose number from January 2015 to January 2018 decreased from 550 to 450 copies in the versions T-80BW (Russian: $T-805 B$ ) and T-80U (Russian: $T-80 Y$ ). The new T-80BWM variant (Russian: T-80 $5 B M$ ) is to become the benchmark standard of modernization for 200 T-80BW tanks (The Military Balance 2015; The Military Balance 2018; Przeździecki, 2017b; Wolski, 2019).

\section{CONCLUSIONS}

The Russian Federation, in view of its intention to preserve its status as a regional power in the future, is forced to continuously modernise and develop all types of troops, including Ground Forces. While it has become clear since 1991 that Russia, despite continuing efforts to implement ambitious plans to rebuild its empire, cannot afford to fund an over-expanded conventional land-based force, has made the greatest progress in this area (since the breakup of the Soviet Union) in 2008-2014.

In 2015-2018, however, the process of modernising the Ground Forces, including their armoured component, although still in progress, significantly reduced their dynamics. This was due to the slowdown in the growth rate of the Russian Federation's GDP, which in turn resulted from the introduction of Western sanctions from 2014, and a drop in global oil and gas prices. These factors forced the Russian state to rationalise its budget spending, which had a direct impact on the scope of modernisation of the armoured component of the Russian Ground Forces in 2015-2018. This also resulted in the final limitation of its modernisation to the qualitative sphere and the abandonment of quantitative expansion. In practice,

${ }^{13}$ At least 31 of the tanks owned by the T-80UD were rebuilt in 2005-2008 to the T-80U-Je1 (Russian: $T-80$ - $E 1$ ) version, while the T-80U (Russian: Т-80УД) was rebuilt (also between 2005 and 2008 year) to the T-80UA variant (Russian: T-80УA). In turn, in the years 1999-2009, about 750 T-72 tanks were rebuilt to the T-72BA version. See: (Wolski, 2019; Kwasek, 2018; Przeździecki, 2017b).

${ }^{14}$ On the details of the modernization to the T-72B3 and T-72B3 standard Mod. 2016. See: (Przeździecki, 2017a; Wolski, 2019). 
the principle of "economic optimization of modernization" was adopted, i.e. an attempt to increase the maximization of combat efficiency combined with the reduction of over-standard costs associated with this process. This means maintaining the number of actives main battle tanks at the current level, while at the same time launching a minimum scale of production of their most technologically advanced types (T-14 Armata) and mass modernization of these variants, which could provide at least for some time a relatively large technological and operational potential on the potential battlefield in the third decade of the $21 \mathrm{st}$ century (advanced versions T-72, T-80 and T-90).

\section{REFERENCES}

Barrie, D., Gethin, H. (2018). Russian Weapons in the Syrian Conflict. „Russian Studies” 02/18, NATO Defense College, May.

Bender, J., These are the plans for Russia's new 3rd-generation tank, „Business Insider”, 30.03.2015 r. [Access: 11.09.2019]. Access on the internet: https://www.businessinsider.com/ plans-for-russias-t-14-armata-tank-2015-3? IR=T

Bowen, A., Coercive Diplomacy and the Donbas: Explaining Russian Strategy in Eastern Ukraine. ,Journal of Strategic Studies”, 2019, Vol. 42, issue 3-4.

Cooper, J. (2018). The Russian State Armament Programme, 2018 - 2027. „Russian Studies” 01/18, NATO Defense College, May.

de Haas, M. (2011). Russia's Military Reforms. Victory after Twenty Years of Failure?, Netherlands Institute of International Relations "Clingendael'. "Clingendael Paper", No. 05, Hague November.

Defence Update: T. Eshel, New Russian Armor - First Analysis: Armata [Access: 11.09.2019]. Access on the internet: https://defense-update.com/20150509_t14-t15_analysis.html Defence24: Czotgi Armata do produkcji seryjnej po 2018 roku [Access: 08.09.2019]. Access on the internet: https://www.defence24.pl/czolgi-armata-do-produkcji-seryjnej-po-2018-roku

Defence24: Sabak J., Czotg T-14 Armata gotów do prób państwowych [Access: 08.09.2019]. Access on the internet: https://www.defence24.pl/czolg-t-14-armata-gotow-do-probpanstwowych

Defence24: Zamówienia na rosyjskie pojazdy Armata [Access: 08.09.2019]. Access on the internet: https://www.defence24.pl/zamowienia-na-rosyjskie-pojazdy-armata

Depczyński, M. (2017). Ewolucja rosyjskich wojsk lądowych. Cz. 1. „Przegląd Sit Zbrojnych”, nr 1.

(2018). Ewolucja rosyjskich wojsk lądowych. Cz. 2. „Przeglad Sit Zbrojnych”, nr 3.

Galeotti, M. (2017). The Modern Russian Army 1992-2016, Oxford-New York: Osprey Publishing, Elite, No. 217.

Galeotti, M. (2019). Armies of Russia's War in Ukraine 1992-2016, Oxford-New York: Osprey Publishing, Elite, No. 228.

Grabowski, T.W. (2011). Rosyjska siła. Sity Zbrojne i główne problemy polityki obronnej Federacji Rosyjskiej w latach 1991-2010. Częstochowa: Instytut Geopolityki.

Jane's Land Warfare Platforms. Armoured Fighting Vehicles 2018-2019 (ed. S. Cranny-Evans, J. Hawkes, S. Nair, O. Widlund), Couldson: IHS Markit, 2018.

Jane's World Armies 2018, Issue 44 (ed. E. Keymer), Couldson: IHS Markit, December 2018.

Kofman, M., Migacheva, K., Nichiporuk, B., Radin A., Tkacheva, O., Oberholtzer, J. (2017). Lessons from Russia's Operations in Crimea and Eastern Ukraine, Santa Monica: RAND Corporation. 
Kwasek, T. (2018). Modernizacja wojsk ladowych - wybrane aspekty. „Nowa Technika Wojskowa", nr spec. 14 (luty).

Martynenko, E.V; Parkhitko, N.P. (2018). Implementation of the Russian State Armaments Program 2011-2020: Economic and Financial Analysis. ,European Research Studies”, t. 21.

Nikonov, A. (2018). T-14 Armata. Tank XXI wieka. „Nashi Tanki”, No. 3.

Ogorkiewicz, R. (2015). Tanks. 100 Years of Evolution. Oxford-New York: Osprey Publ.

Przeździecki, P. (2017a) Czołg podstawowy T-72B3. „,Wojsko i Technika”, nr 8.

- (2017b). T-80BWM. „Wojsko i Technika”, nr 11.

— (2017c). T-90M - nowy czotg rosyjskiej armii. „Wojsko i Technika”, nr 11.

Roblin S., No 'Silver Bullet': Why Russia's New Tank Round Has a Problem, „The National Interest" [Access: 17.09.2019]. Access on the internet: https://nationalinterest.org/blog/buzz/ no-silver-bullet-why-russias-new-tank-round-has-problem-54862

Russia Military Power. Buildinga Military to Support Great Power Aspirations (2017). Washington D.C.: Defense Intelligence Agency.

SIPRI Military Expediture Database. Data for all countries 1949-2018 (excel spreadsheet) [Access: 16.09.2019]. Access on the internet: https://www.sipri.org/databases/milex

Sutyagin, I., Bronk, J. (2017). Russia's New Ground Forces. Capabilities, Limitations and Implications for International Security, Whitehall Papers, RUSI-Routledge, Colchester-Philadelphia.

Suworow, S. (2003). T-90 - pierwszy seryjny czotg Rosji. Historia powstania i wersje Rozwojowe. „Nowa Technika Wojskowa”, nr 2.

Tank T-14 "Armata" can "save" the export order and the 120-mm gun, "WeapoNews" [Access: 17.09.2019]. Access on the internet: 26.02.2019 r., https://weaponews.com/news/ 65347679-tank-t-14-armata-can-save-the-export-order-and-the-120-mm-gun.html

The Military Balance 2011, International Institute for Strategic Studies, London 2011.

The Military Balance 2015, International Institute for Strategic Studies-Routledge, London 2015.

The Military Balance 2016, International Institute for Strategic Studies-Routledge, London 2016.

The Military Balance 2017, International Institute for Strategic Studies-Routledge, London 2017.

The Military Balance 2018, International Institute for Strategic Studies-Routledge, London 2018.

The Military Balance 2019, International Institute for Strategic Studies-Routledge, 2019.

The World Factbook 1991, Central Intelligence Agency, Washington D.C. 1991.

Wolski, J. (2016). Tendencje rozwojowe przeciwpancernych pocisków podkalibrowych. „Nowa Technika Wojskowa”, nr 9.

(2018a). Anatomia pancerza T-90. Cz. 1. „Nowa Technika Wojskowa”, nr 6.

(2018b). Anatomia pancerza T-90. Cz. 2. „Nowa Technika Wojskowa”, nr 7.

(2019). Rosyjskie wojska pancerne. Potencjat i kierunki zmian. „Nowa Technika Wojskowa”, nr 2.

World Bank Data: GDP (current US\$) - World's Countries 2018 [Access: 16.09.2019]. Access on the internet: https://data. worldbank.org/indicator/NY.GDP.MKTP.CD?end=2018

\&most_recent_value_desc $=$ true 
World Bank Data: GDP per capita (current US\$) - World's Countries [Access: 16.09.2019]. Access on the internet: https://data.worldbank.org/indicator/ NY.GDP.PCAP.CD

World Bank Data: Total Population - World's Countries [Access: 16.09.2019]. Access on the internet: https://data.worldbank.org/indicator/SP.POP.TOTL? locations=RU.

World Bank Data:GDP (current US\$) - Russian Federation [Access: 16.09.2019]. Access on the internet:https://data.worldbank.org/indicator/NY.GDP.MKTP.CD?end=2018\&locations= RU\&start=1999\&view $=$ chart

World Bank Data:GDP (current US\$) - World's Countries 2015 [Access: 16.09.2019]. Access on the internet: https://data. worldbank.org/indicator/NY.GDP.MKTP.CD?end= 2015\&most_recent_value_desc=true 1

DOI: $10.7862 /$ rz.2019.hss.41

The text was submitted to the editorial office: November 2019.

The text was accepted for publication: December 2019. 
